\title{
Fatty Acid and Hydrocarbon Constituents of the Surface and Wall Lipids of Some Fungal Spores
}

\author{
By D. J. FISHER, P. J. HOLLOWAY AND D. V. RICHMOND \\ Long Ashton Research Station, University of Bristol, Bristol, BS I8 9 AF
}

(Accepted for publication 17 March 1972)

\begin{abstract}
SUMMARY
Microelectrophoresis has shown surface lipid to be present on conidia of Alternaria tenuis, Botrytis fabae and Neurospora crassa and on sporangiospores of Rhizopus stolonifer. Surface lipid is absent from conidia of Erysiphe cichoracearum, E. graminis, Nectria galligena, Penicillium expansum and Verticillium albo-atrum and sporangiospores of Mucor rouxii. The compositions of the fatty acid and hydrocarbon fractions of the surface and wall lipids from the same organisms are different. The fatty acids are mainly straight-chain and even carbon-numbered. Palmitic and stearic acids predominate. Polyunsaturated acids were absent. Surface hydrocarbons consist almost entirely of $n$-alkanes but wall fractions are more complex. An equal distribution of odd and even carbon-numbered alkanes occurs in both the surface and wall lipid fractions.
\end{abstract}

\section{INTRODUCTION}

Many airborne fungal spores have a water-repellent surface which aids dispersal, prevents desiccation and may provide a barrier to the entry of toxicants. This surface may consist largely of waxy material (Emeis, 1958; Laseter, Weete \& Weber, I968b) but there are few reports in which the presence of surface lipid has been confirmed chemically. Crystalline spicules of cyclic peptides together with some lipid occur on the surface of Pithomyces chartarum spores (Bertaud, Morice, Russell \& Taylor, 1963) but the lipids reported from the surface of various smut spores (Oró, Laseter \& Weber, 1966) may be intracellular (Weete, Laseter, Weber, Hess \& Stocks, 1969).

Surface lipid can be detected by the increase in electrophoretic mobility produced in the presence of anionic surface-active agents such as sodium dodecyl sulphate (SDS) (James, 1965). By means of this technique surface lipid was detected on conidia of Neurospora crassa, Alternaria tenuis and Botrytis fabae (Somers \& Fisher, 1967; Fisher \& Richmond, 1969).

In the present study other fungal spores are examined for surface lipid. The fatty acids and hydrocarbons of the surface are compared with those in spore walls.

\section{METHODS}

Organisms. Neurosopora crassa Shear and Dodge wild-type 529a and Mucor rouxii (Calmette) Wehm. were obtained from the Commonwealth Mycological Institute, Kew, Penicillium expansum Link ex Thom from the Bath University culture collection, and Rhizopus stolonifer (Ehrenb. ex Fr.) Lind from the Botany Department, University of Bristol. Alternaria tenuis Nees, Botrytis fabae Sardiña, Erysiphe graminis DC ex Mérat, Erysiphe cichoracearum $\mathrm{DC}$ and Nectria galligena Bres. were obtained from naturally infected material at Long Ashton Research Station. 
Composition of culture media and isolation of spore walls. Alternaria tenuis was cultured on carrot agar, Botrytis fabae on peptone medium (Hislop, 1967), Nectria galligena on potatocarrot agar, Neurospora crassa on modified Fries medium (Richmond \& Somers, 1962), Mucor rouxii on tomato juice agar (Haidle \& Storck, 1966) and Penicillium expansum and Rhizopus stolonifer on malt agar. All cultures were grown at $25^{\circ} \mathrm{C}$ except $B$. fabae $\left(16{ }^{\circ} \mathrm{C}\right)$.

Spores were harvested after 7 days of growth (Richmond \& Somers, 1963). Conidia of Erysiphe graminis and E. cichoracearum were washed from infected oat seedlings (var. Black Supreme) and marrow plants (var. Green Bush) respectively. The collected spores were freeze-dried. Spore walls were prepared from spores from which the surface lipid had been removed (see below). Dense spore suspensions were shaken with an equal volume of Ballotini (no. I2) beads in a Mickle disintegrator at $4{ }^{\circ} \mathrm{C}$ for $15 \mathrm{~min}$ (Somers \& Fisher, I967). The centrifuged spore walls were freed from cytoplasmic contaminants by washing ten times with $10 \%(\mathrm{w} / \mathrm{v})$ sucrose, five times with $0.9 \%(\mathrm{w} / \mathrm{v}) \mathrm{NaCl}$ and five times with water (Dyke, 1964). The walls were then dried over $\mathrm{P}_{2} \mathrm{O}_{5}$ under vacuum at room temperature.

Electrophoretic measurements. Mobilities were measured in a laterally mounted rectangular microelectrophoresis cell enclosed in a water bath at $25^{\circ} \mathrm{C} \pm 0.2{ }^{\circ} \mathrm{C}$ (Fisher \& Richmond, 1969). Spores were suspended in phosphate buffer $\left(\mathrm{pH} 77^{\circ}, I: 0.0 \mathrm{I}\right)$ or in buffer containing I $\mu \mathrm{M}$, 10 $\mu \mathrm{M}$ or I00 $\mu \mathrm{M}-\mathrm{SDS}$ (Hill, James \& Maxted, 1963). These concentrations of SDS were not high enough to alter significantly the $\mathrm{pH}$ value, ionic strength or conductivity of the buffer solution. Each mobility was the mean of at least 20 observations; the standard error of the mean was less than $4 \%$.

Extraction and separation of fungal lipid. Surface lipids were removed from freeze-dried spores (about $2 \mathrm{~g}$ ) by suspension in light petroleum (boiling range 40 to $60{ }^{\circ} \mathrm{C}$ ) for $\mathrm{I}$ min at $25^{\circ} \mathrm{C}$. Wall lipids were extracted with chloroform + methanol $(2+\mathrm{I}, \mathrm{v} / \mathrm{v})$ for $\mathrm{I} 8 \mathrm{~h}$ in a Bolton extractor. The suspensions were centrifuged and the supernatant fractions were filtered through ether-extracted cotton wool. The solvents were removed in a rotary evaporator at $40^{\circ} \mathrm{C}$. Lipids were separated into fatty acid and hydrocarbon fractions by thinlayer chromatography (t.l.c.) on silica gel G (Merck Ag., Darmstadt, Germany) with light petroleum $\left(40\right.$ to $\left.60{ }^{\circ} \mathrm{C}\right)+$ diethylether + acetic acid $(90+\mathrm{IO}+\mathrm{I}, \mathrm{v} / \mathrm{v})$ as solvent (Malins \& Mangold, 1960). The fractions were detected by spraying the plate with chlorosulphonic acid + acetic acid $(\mathrm{I}+2, \mathrm{v} / \mathrm{v})$ and charring in an oven at $200^{\circ} \mathrm{C}(\mathrm{Krebs}$, Heusser \& Wimmer, 1969). Fatty acids were methylated by the addition of freshly prepared diazomethane in ether before gas-liquid chromatography (g.l.c.).

Gas-liquid chromatography (g.l.c.). A Hewlett-Packard 5750 gas chromatograph fitted with dual columns and flame-ionization detectors and o to $\mathrm{I} \mathrm{mV}$ recorder was used. Retention data were determined by means of both OV210 (3\% loading) and E3OI $(5 \%$ or $8 \%$ loading) on 80- to I00-mesh Chromosorb W-HP. The chromatographic columns were of stainless steel $2 \mathrm{~mm}$ internal diameter and $\mathrm{r} .8 \mathrm{~m}$ in length. The carrier gas was nitrogen, flow rate $40 \mathrm{ml} / \mathrm{min}$ (70 p.s.i.). The detectors were maintained at $300^{\circ} \mathrm{C}$ and the injection inlet at $250^{\circ} \mathrm{C}$. Analyses were made with temperature programming at a rate of $2{ }^{\circ} \mathrm{C}$ per min from $\mathrm{I}_{50}$ to $300{ }^{\circ} \mathrm{C}$ (E $\left.30 \mathrm{I}\right)$ and 100 to $230^{\circ} \mathrm{C}$ (OV $\left.2 \mathrm{IO}\right)$. The principal peaks were identified by comparison of retention times with those of known standards. Minor constituents were identified by use of a plot of the $\log$ of the retention time versus carbon number. Relative peak areas were measured from the chart by the triangulation method. 
Table I. Effect of sodium dodecyl sulphate $(S D S)$ on the electrophoretic mobility of spores and isolated spore walls

Suspension medium: phosphate buffer solution ( $\mathrm{pH} 7 \cdot 0, I: 0 \cdot 0 \mathrm{I})$

\begin{tabular}{|c|c|c|c|c|}
\hline \multirow[b]{2}{*}{ Material } & \multirow{2}{*}{$\begin{array}{l}\text { Electrophoretic } \\
\text { mobility, } \\
\text { IO }^{-8} \mathrm{~m}^{2} \mathrm{~V}^{-1} \mathrm{~S}^{-1}\end{array}$} & \multicolumn{3}{|c|}{$\begin{array}{c}\text { Percentage increase in negative mobility } \\
\text { Concentration of SDS }\left(\mu_{\mathrm{M})}\right.\end{array}$} \\
\hline & & I & 10 & 100 \\
\hline \multicolumn{5}{|l|}{ Intact spores } \\
\hline Alternaria tenuis* & $-2 \cdot 62$ & $\mathbf{I 5}$ & I6 & 24 \\
\hline Botrytis fabae & $-\mathrm{I} \cdot 54$ & 5 & 6 & 15 \\
\hline Erysiphe cichoracearum & -0.80 & 0 & 0 & 0 \\
\hline E. graminis & -3.54 & 0 & $\mathbf{I}$ & 2 \\
\hline Mucor rouxii & $-I \cdot 72$ & 6 & 6 & 4 \\
\hline Nectria galligena & $-3 \cdot 75$ & 0 & 0 & 0 \\
\hline Neurospora crassa & -0.45 & 7 & 9 & 24 \\
\hline Penicillium expansum* & $-I \cdot 54$ & 17 & 14 & I4 \\
\hline Rhizopus stolonifer & $-1 \cdot 78$ & 3 & 5 & 33 \\
\hline Verticillium albo-atrum & $-I \cdot 27$ & 0 & 0 & 0 \\
\hline \multicolumn{5}{|l|}{ Spore walls } \\
\hline Alternaria tenuis & $-I \cdot 55$ & 2 & 5 & II 2 \\
\hline Botrytis fabae* & $-I \cdot 4 I$ & 3 & 6 & 9 \\
\hline Neurospora crassa $\dagger$ & -0.69 & - & 78 & 130 \\
\hline Penicillium expansum* & $-I \cdot 52$ & - & 3 & 3 \\
\hline
\end{tabular}

Table 2. Surface and wall lipids of some fungal spores

Spores were grown and harvested as described in the text. Surface lipid was removed from freezedried spores by suspension in light petroleum (boiling range 40 to $60^{\circ} \mathrm{C}$ ) for I min at $25^{\circ} \mathrm{C}$. Wall lipids were extracted from purified cell walls free of surface lipid (for details see text) with chloroform + methanol $(2+I, v / v)$ for $\mathbf{I} 8 \mathbf{h}$ in a Bolton extractor. Fatty acids were determined by extraction from preparative t.l.c. plates with chloroform + methanol.

\begin{tabular}{lccc}
\multicolumn{1}{c}{ Organism } & $\begin{array}{c}\text { Surface lipid as } \\
\text { percentage spore } \\
\text { dry weight }\end{array}$ & $\begin{array}{c}\text { Wall lipid as } \\
\text { percentage wall } \\
\text { dry weight }\end{array}$ & $\begin{array}{c}\text { Fatty acid } \\
\text { as percentage } \\
\text { wall lipid }\end{array}$ \\
Alternaria tenius & 0.15 & 1.67 & 18 \\
Botrytis fabae & 0.19 & 5.08 & 31 \\
Neurospora crassa & 0.17 & 8.95 & 6 \\
Penicillium expansum & Not detected & $1 \cdot 10$ & $3 \mathrm{I}$ \\
Rhizopus stolonifer & 0.20 & 3.97 & 12
\end{tabular}

RESULTS

Electrokinetic measurements. The electrophoretic mobility of spores of Alternaria tenuis, Botrytis fabae, Neurospora crassa and Rhizopus stolonifer rose progressively in increasing concentrations of SDS, indicating the presence of some surface lipid (Table I). The mobility of Penicillium expansum conidia in $\mathrm{r} \mu \mathrm{M}$-SDS also increased but the absence of any further rise at higher SDS concentrations indicated the probable absence of surface lipid. The mobilities of spores of other species were unaffected by the presence of SDS. Mobilities of isolated spore walls confirmed the results obtained with whole spores (Table r).

Analysis of lipid fractions. Only small amounts of surface lipid were present on freezedried spores (Table 2) and lipid was absent from surfaces of Penicillium expansum conidia, 


\section{Table 3 Relative composition of surface and wall fatty acids}

The lipid extracted from surface and walls of fungal spores (see text for details of culture media and extraction procedures) was esterified with diazomethane, separated by t.l.c. and analysed by g.l.c. The percentage $(w / w)$ of each fatty acid was calculated from peak areas.

\begin{tabular}{|c|c|c|c|c|c|c|c|c|c|}
\hline \multirow{3}{*}{$\begin{array}{l}\text { Fatty } \\
\text { acid }\end{array}$} & \multicolumn{9}{|c|}{ Percentage of total fatty acids } \\
\hline & \multicolumn{2}{|c|}{$\begin{array}{l}\text { Rhizopus } \\
\text { stolonifer }\end{array}$} & \multicolumn{2}{|c|}{$\begin{array}{c}\text { Alternaria } \\
\text { tenuis }\end{array}$} & \multicolumn{2}{|c|}{$\begin{array}{l}\text { Botrytis } \\
\text { fabae }\end{array}$} & \multicolumn{2}{|c|}{$\begin{array}{c}\text { Neurospora } \\
\text { crassa }\end{array}$} & \multirow{2}{*}{$\begin{array}{c}\text { Penicilliun } \\
\text { expansum } \\
\text { Wall }\end{array}$} \\
\hline & Surface & Wall & Surface & Wall & Surface & Wall & Surface & Wall & \\
\hline I $2: 1$ & - & - & 0.4 & - & - & - & - & - & - \\
\hline $12: 0$ & $3 \cdot I$ & $5 \cdot 3$ & $2 \cdot 2$ & $2 \cdot 8$ & $3 \cdot 1$ & $4 \cdot 7$ & $3 \cdot I$ & $I \cdot 4$ & 1.4 \\
\hline $13: 1$ & $t$ & - & 0.3 & - & 0.8 & - & 0.8 & - & - \\
\hline $13: 0$ & $t$ & - & $t$ & - & 0.4 & - & 0.5 & - & - \\
\hline $14: 1$ & $1 \cdot 6$ & - & $I \cdot 3$ & - & $3 \cdot 3$ & 0.4 & $t$ & $I \cdot 3$ & $2 \cdot 7$ \\
\hline $14: 0$ & $8 \cdot 5$ & $6 \cdot 0$ & $8 \cdot 4$ & 4.9 & $8 \cdot 8$ & $6 \cdot 3$ & $10 \cdot 3$ & $4 \cdot 3$ & $2 \cdot 0$ \\
\hline$?$ & $t$ & - & 0.4 & - & 0.8 & - & $I \cdot I$ & - & - \\
\hline $15: I$ & $1 \cdot 0$ & - & $1 \cdot 3$ & $I \cdot 4$ & $\mathrm{I} \cdot 2$ & 0.4 & $I \cdot 2$ & 0.9 & - \\
\hline $15: 0$ & $1 \cdot 8$ & $3 \cdot 0$ & $1 \cdot 7$ & $4 \cdot 6$ & $1 \cdot 5$ & $3 \cdot 9$ & $2 \cdot 3$ & $2 \cdot 4$ & $2 \cdot 3$ \\
\hline$?$ & $3 \cdot 8$ & - & $3 \cdot 2$ & - & $5 \cdot 2$ & - & $I \cdot I$ & - & - \\
\hline $16: 1$ & 3.6 & - & $2 \cdot 5$ & $5 \cdot 3$ & $5 \cdot 5$ & $1 \cdot 2$ & 一 & $\mathrm{I} \cdot 8$ & $\mathrm{t}$ \\
\hline $16: 0$ & $4 I \cdot 3$ & $33 \cdot 3$ & $28 \cdot 7$ & $41 \cdot 7$ & $27 \cdot 9$ & $22 \cdot 7$ & $40 \cdot 3$ & $47 \cdot 3$ & 306 \\
\hline$?$ & $2 \cdot I$ & - & I. 5 & -1 & $1 \cdot 8$ & - & $3 \cdot 2$ & - & - \\
\hline $17: 1$ & $2 \cdot 5$ & 3.0 & 1.8 & - & $2 \cdot 6$ & $3 \cdot 3$ & $2 \cdot 7$ & $2 \cdot 8$ & 0.8 \\
\hline $17: 0$ & $2 \cdot 7$ & - & $2 \cdot 4$ & $4 \cdot 9$ & $I \cdot 3$ & $5 \cdot 6$ & $\mathrm{I} \cdot 6$ & 6.5 & $1 \cdot 7$ \\
\hline$?$ & - & - & - & $7 \cdot 4$ & - & - & - & $\mathrm{t}$ & $I \cdot 7$ \\
\hline $18: 1$ & $2 \cdot 7$ & 12.0 & 3.0 & 4.9 & $2 \cdot I$ & $9 \cdot 6$ & $t$ & $4 \cdot 6$ & $38 \cdot 7$ \\
\hline I 8:0 & 14.9 & 18.3 & 14.8 & $22 \cdot 2$ & $11 \cdot 2$ & 10.8 & $17 \cdot 5$ & 13.5 & II 5 \\
\hline $19: 1$ & - & 6.0 & - & - & - & $t$ & - & - & I. O \\
\hline $19: 0$ & $2 \cdot 1$ & 8.0 & $2 \cdot 6$ & - & $1 \cdot 6$ & $t$ & $1 \cdot 4$ & - & - \\
\hline $20: 1$ & - & - & I.5 & - & $3 \cdot I$ & - & $2 \cdot 2$ & $4 \cdot 3$ & - \\
\hline $20: 0$ & $2 \cdot 2$ & $1 \cdot 7$ & $5 \cdot 5$ & - & - & $I \cdot 4$ & $1 \cdot 5$ & $2 \cdot 5$ & - \\
\hline $2 \mathrm{I}: \mathrm{I}$ & $2 \cdot 7$ & - & $1 \cdot 5$ & - & - & - & - & - & - \\
\hline $21: 0$ & $t$ & - & $\mathrm{I} \cdot \mathrm{O}$ & - & $2 \cdot 2$ & $I \cdot 3$ & $I \cdot 3$ & 2.0 & - \\
\hline$?$ & - & - & 0.9 & - & - & - & - & - & - \\
\hline $22: 1$ & - & $I \cdot 3$ & $I \cdot O$ & - & $2 \cdot 7$ & - & 0.7 & $I \cdot 4$ & $2 \cdot I$ \\
\hline $22: 0$ & $3 \cdot 4$ & $2 \cdot 0$ & $6 \cdot 2$ & - & $I \cdot I$ & - & $2 \cdot 8$ & $\mathrm{I} \cdot 4$ & $2 \cdot 5$ \\
\hline $23: 1$ & 34 & - & - & - & - & 8.6 & - & - & - \\
\hline $23: 0$ & - & - & 1.8 & - & $2 \cdot I$ & I6.3 & $I \cdot 6$ & $I \cdot 6$ & - \\
\hline $24: I$ & - & - & - & - & - & - & I. 6 & - & - \\
\hline $24: 0$ & $t$ & - & $2 \cdot 0$ & - & $I \cdot 4$ & $3 \cdot 5$ & $I \cdot 2$ & - & $\mathrm{I} \cdot \mathrm{I}$ \\
\hline $25: 1$ & - & - & $t$ & - & $I \cdot 2$ & - & - & - & - \\
\hline $25: 0$ & - & - & $I \cdot 3$ & - & 3.4 & - & - & - & - \\
\hline $26: 1$ & - & - & 0.8 & - & 1.6 & - & - & - & - \\
\hline $26: 0$ & - & - & $t$ & - & $2 \cdot I$ & - & - & - & - \\
\hline
\end{tabular}

$-=$ Not detected, $\mathrm{t}=$ trace detected, $?=$ unidentified fatty acids.

confirming the electrophoretic results. Fatty acids, hydrocarbons and phospholipids were present in both surface and wall extracts. The surface extract consisted mainly of fatty acids. The amounts of fatty acids in the walls of different species varied considerably. Walls of $P$. expansum contained only a small amount of lipid, comparable to the amount in mycelial walls of $P$. notatum (Applegarth, I967).

Surface and wall fatty acid composition. From 10 to 18 different fatty acids were found in the spore-wall lipids and 22 to $3 \mathrm{r}$ in the surface lipids (Table 3). The total lipids from fungal spores or mycelium usually contain far fewer fatty acids (Shaw, 1966). The surface acids were mainly saturated with even numbers of carbon atoms. Myristic, palmitic and stearic 
Table 4. Relative composition of surface and wall hydrocarbons

The lipid extracted from surface and walls of fungal spores (see text for details of culture media and extraction procedures) was separated by t.l.c. and analysed by $g .1 . c$. The percentage (w/w) of each hydrocarbon was calculated from peak areas.

\begin{tabular}{|c|c|c|c|c|c|c|c|c|c|}
\hline \multirow{3}{*}{$\begin{array}{l}\text { Hydro- } \\
\text { carbon }\end{array}$} & \multicolumn{9}{|c|}{ Percentage of total hydrocarbons } \\
\hline & \multicolumn{2}{|c|}{$\begin{array}{l}\text { Rhizopus } \\
\text { stolonifer }\end{array}$} & \multicolumn{2}{|c|}{$\begin{array}{c}\text { Alternaria } \\
\text { tenuis }\end{array}$} & \multicolumn{2}{|c|}{$\begin{array}{l}\text { Botrytis } \\
\text { fabae }\end{array}$} & \multicolumn{2}{|c|}{$\begin{array}{c}\text { Neurospora } \\
\text { crassa }\end{array}$} & \multirow{2}{*}{$\begin{array}{c}\text { Penicillium } \\
\text { expansum } \\
\text { Wall }\end{array}$} \\
\hline & Surface & Wall & Surface & Wall & Surface & Wall & Surface & Wall & \\
\hline$n-\mathrm{C}_{16}$ & - & 0.5 & - & $I \cdot O$ & - & 0.6 & - & - & $t$ \\
\hline ? & - & 0.5 & - & 一 & - & $I \cdot 3$ & - & $t$ & - \\
\hline$n-C_{17}$ & - & $3 \cdot 3$ & - & $2 \cdot I$ & - & $2 \cdot I$ & - & $3 \cdot 2$ & - \\
\hline$?$ & - & $I \cdot 6$ & - & I. 5 & - & 0.8 & - & 0.7 & 3.6 \\
\hline$?$ & $\longrightarrow$ & - & - & $\mathrm{t}$ & - & - & - & 0.7 & - \\
\hline$n-C_{18}$ & $t$ & 5.5 & $3 \cdot 2$ & $2 \cdot 0$ & $\mathbf{I} \cdot \mathbf{I}$ & $I \cdot 2$ & - & $3 \cdot 2$ & $3 \cdot 3$ \\
\hline$?$ & - & $3 \cdot 3$ & - & $I \cdot O$ & - & $2 \cdot I$ & - & $2 \cdot 8$ & $6 \cdot 7$ \\
\hline$n-C_{19}$ & 0.2 & $2 \cdot 5$ & I I $\cdot 2$ & $3 \cdot I$ & $2 \cdot 3$ & $I \cdot 7$ & $8 \cdot 1$ & $2 \cdot I$ & $2 \cdot 7$ \\
\hline$?$ & 一 & $I \cdot I$ & - & $4 \cdot 6$ & - & $2 \cdot 9$ & - & $2 \cdot 8$ & $x \cdot 8$ \\
\hline$?$ & - & - & - & - & - & 0.3 & - & - & - \\
\hline$?$ & - & - & - & - & - & - & $I \cdot 9$ & - & - \\
\hline$n-C_{20}$ & $5 \cdot 2$ & $I \cdot 6$ & 14.5 & $2 \cdot 0$ & 13.6 & 0.8 & $28 \cdot I$ & $2 \cdot I$ & $2 \cdot 0$ \\
\hline$?$ & - & $5 \cdot 7$ & - & $6 \cdot 1$ & - & $6 \cdot 7$ & - & 10.6 & 8.9 \\
\hline$n-C_{21}$ & $12 \cdot 4$ & I. 4 & $12 \cdot I$ & $4 \cdot 6$ & $22 \cdot 7$ & $2 \cdot I$ & $21 \cdot 0$ & $2 \cdot I$ & $I \cdot 8$ \\
\hline$?$ & - & - & - & - & - & $16 \cdot 3$ & - & - & - \\
\hline$?$ & - & $7 \cdot 7$ & - & 13.8 & - & I 2.9 & - & 0.5 & $9 \cdot 4$ \\
\hline$n-C_{22}$ & 15.5 & $2 \cdot 5$ & $4 \cdot 8$ & $2 \cdot 6$ & 19.3 & $2 \cdot 0$ & 10.9 & $11 \cdot 2$ & 8.0 \\
\hline$?$ & - & $13 \cdot 1$ & 2.4 & 26.8 & - & - & - & 2.4 & $2 \mathrm{I} \cdot 4$ \\
\hline$n-C_{23}$ & I 4.5 & 4.9 & 8.0 & $4 \cdot 6$ & $11 \cdot 4$ & $3 \cdot 4$ & $6 \cdot 2$ & $4 \cdot 2$ & $t$ \\
\hline ? & - & $t$ & - & $I \cdot 0$ & - & 5.5 & - & 0.9 & $2 \cdot 7$ \\
\hline$n-C_{24}$ & 15.6 & $6 \cdot 6$ & $6 \cdot 4$ & $14 \cdot 3$ & 10.2 & $7 \cdot 3$ & 5.0 & $9 \cdot 3$ & $8 \cdot 9$ \\
\hline$n-C_{25}$ & I3.I & 4.9 & 10.0 & $2 \cdot 3$ & $5 \cdot 7$ & 2.5 & $4 \cdot 4$ & 3.5 & $2 \cdot 7$ \\
\hline$n-C_{26}$ & $8 \cdot 3$ & $6 \cdot 8$ & $8 \cdot 0$ & 3.8 & $4 \cdot 5$ & $4 \cdot 2$ & $3 \cdot I$ & 5.8 & $2 \cdot 7$ \\
\hline$n-C_{27}$ & $6 \cdot 2$ & 49 & $I .6$ & I. 5 & $2 \cdot 3$ & 3.9 & $3 \cdot 1$ & 5.6 & $2 \cdot 7$ \\
\hline$?$ & - & - & - & 二 & - & $2 \cdot I$ & - & 6.9 & - \\
\hline$n-C_{28}$ & $4 \cdot 2$ & $2 \cdot 7$ & $8 \cdot 0$ & $I \cdot 0$ & $6 \cdot 8$ & $3 \cdot 4$ & $3 \cdot 9$ & 0.7 & - \\
\hline$?$ & - & - & - & - & - & 0.6 & - & - & - \\
\hline$n-\mathrm{C}_{29}$ & $2 \cdot 6$ & $12 \cdot 3$ & $4 \cdot 8$ & 一 & $t$ & $4 \cdot 9$ & $1 \cdot 9$ & $7 \cdot 5$ & $2 \cdot 7$ \\
\hline$?$ & - & - & - & - & - & $2 \cdot 2$ & - & $2 \cdot 9$ & - \\
\hline$n-\mathrm{C}_{30}$ & $I \cdot 3$ & $3 \cdot 3$ & $2 \cdot 4$ & 一 & - & $2 \cdot 8$ & $I \cdot 3$ & $\mathrm{I} \cdot 8$ & $4 \cdot 7$ \\
\hline$n-C_{31}$ & 0.6 & $3 \cdot 3$ & $2 \cdot 4$ & - & - & $2 \cdot I$ & 0.7 & 5.2 & $\mathrm{I} \cdot 3$ \\
\hline$?$ & - & - & - & - & - & 0.8 & - & $\mathbf{t}$ & - \\
\hline $\begin{array}{l}n-\mathrm{C}_{32} \\
\text { Carbon }\end{array}$ & 0.3 & - & - & 一 & - & 0.6 & 0.5 & $I \cdot 4$ & $2 \cdot 0$ \\
\hline $\begin{array}{l}\text { preference } \\
\text { index }\end{array}$ & ce 0.99 & & I.06 & & 0.80 & & 0.86 & & \\
\hline
\end{tabular}

$-=$ Not detected, $\mathrm{t}=$ trace detected, $?=$ unidentified hydrocarbon.

were the most abundant acids. Although spore walls had similar fatty acid components to surface fractions there were numerous quantitative differences. The $C_{23: 0}$ and $C_{23: 1}$ acids were major components of Botrytis fabae conidial walls. Walls of Penicillium expansum contained a relatively high proportion of unsaturated acids; oleic was the main acid present.

Surface and wall hydrocarbon components. Surface hydrocarbons consisted almost entirely of $n$-alkanes which ranged from $\mathrm{C}_{18}$ to $\mathrm{C}_{32}$ (Table 4). Carbon-preference ratios (ratio of $\mathrm{C}$ odd to $\mathrm{C}$ even compounds) approximated unity. Surface hydrocarbons from Alternaria tenuis showed a random distribution with major peaks corresponding to $\mathrm{C}_{19}, \mathrm{C}_{20}, \mathrm{C}_{21}, \mathrm{C}_{233}$ $\mathrm{C}_{25}, \mathrm{C}_{26}$ and $\mathrm{C}_{28}$. Hydrocarbons from the surface of Botryis fabae and Neurospora crassa 
showed maxima at the lower end of this series with main peaks at $\mathrm{C}_{20}, \mathrm{C}_{21}$ and $\mathrm{C}_{22}$. Rhizopus stolonifer had a maximum distribution of surface alkanes in the $\mathrm{C}_{21}-\mathrm{C}_{25}$ range. Wall alkanes ranged from $\mathrm{C}_{16}$ to $\mathrm{C}_{32}$. The distribution patterns of $n$-alkanes in the walls (Table 4) differed widely from those of the corresponding surface fractions and the major peaks did not coincide.

\section{DISCUSSION}

Various extraction procedures have been used by other workers to remove surface lipid from fungal spores. Bertaud et al. (1963) extracted fatty acids from the surface of Pithomyces chartarum spores by Io successive benzene washes at room temperature each of I min, while Laseter et al. I968a, b extracted spores of Ustilago maydis and three species of Tilletia with chloroform + benzene $(3+\mathrm{I})$ for $30 \mathrm{~min}$ at $50^{\circ} \mathrm{C}$. Although teliospores of Tilletia germinate after the $50{ }^{\circ} \mathrm{C}$ extraction with chloroform + benzene (Trione \& Te May Ching, 197I) there remains the possibility that some wall or intracellular lipid may have been extracted. Our less rigorous extraction procedure is similar to that employed by Kaneda (I969) in studies of surface waxes on leaves. The usefulness of the electrophoretic technique for detecting surface lipid was demonstrated when lipid was easily removed from the surfaces of those spores which showed a progressive increase in mobility in the presence of SDS.

Surface and wall lipids were mainly saturated. Polyunsaturated acids, such as linoleic which is almost universally present in the cellular lipids of fungi (Shaw, 1966), were not detected in any of the surface or wall lipids examined. This suggests that the spore walls were free from cytoplasmic contamination. Fatty acids in cell walls of the yeast Nadsonia elongata are also mainly saturated while unsaturated acids predominate in whole cells (Dyke, 1964). Similarly, large amounts of palmitic acid occur in teliospore walls of Tilletia controversa (Laseter et al. 1968 a), while linoleic is the most abundant acid inside the spores (Trione \& Te May Ching, 197I). The presence of $\mathrm{C}_{23}$ and $\mathrm{C}_{23: 1}$ acids as major components of Botrytis fabae conidial walls is interesting as these acids have not previously been reported in any quantity from living organisms.

The surface lipids had an almost equal distribution of alkanes with odd and even numbers of carbon atoms. A similar alkane distribution occurs in the total mycelial lipids from Debaryomyces hansenii (Merdinger \& Devine, 1965), Trichoderma viride, Penicillium sp., Aspergillus sp. and Saccharomyces sp. (Jones, 1969). In contrast the major peaks in the surface alkanes of smut spores are of the 'odd' series (Oró et al. 1966; Laseter et al. 1968a,b).

In contrast with the surface fractions, a considerable proportion of the wall hydrocarbons including some of the major peaks were not identified, indicating a high degree of unsaturation or branching. Carbon-preference ratios of hydrocarbons in wall fractions cannot therefore be determined accurately. Wall hydrocarbons ranged from $\mathrm{C}_{16}$ to $\mathrm{C}_{32}$. The distribution patterns of hydrocarbons in the walls (Table 4) differed widely from the patterns of the corresponding surface fractions and the major peaks did not coincide. In contrast to the fatty acids a larger number of hydrocarbons were found in the wall lipids (2I to 30) than in the surface lipids (I 2 to 15 ).

Stránský, Streibl \& Herout (1967) found that the ratio of odd to even carbon-numbered alkanes was approximately unity in primitive plants, whereas in cuticular waxes of higher plants the odd number homologues predominated. Herbin \& Robins (I969) suggested that in higher plants where $n$-alkanes form only a small proportion of the leaf cuticular wax the dominance of odd over even carbon number chain lengths tends to disappear. As the hydrocarbons in the total leaf lipids have a flat distribution of chain lengths, Herbin \& Robins (1969) suggest that the differences which Stránský et al. (1967) ascribe to plants of higher and 
lower evolutionary levels may be more a reflection of the qualitative differences between internal and external lipids: where 'wax' has been obtained by extraction of total lipids the external lipids will be quantitatively more significant in higher plants. Our results for the surface and wall hydrocarbons of fungal spores support the views of Stránský et al. (1967) that in lower plants the ratio of odd to even carbon-numbered alkanes approaches unity.

The absence of any correlation between fatty acids and alkanes makes it unlikely that hydrocarbons are formed by the direct decarboxylation of fatty acids. Oró, Tornabene, Nooner \& Gelpi (1967) found a similar lack of relationship in a number of algae and bacteria.

The spores on which surface lipid was found are airborne and difficult to wet. The absence of surface lipid from spores which are water-dispersed, such as Verticillium albo-atrum and Nectria galligena, is not surprising. Other spores, such as Erysiphe cichoraceorum, E. graminis and Penicillium expansum which lack surface lipids, are neverless hydrophobic. Douglas, Ruddick \& Williams (1970) found a similar lack of correlation between water-repellent properties and the presence of surface lipid in actinomycete spores. Conidia of Penicillium (Hess, Sassen \& Remsen, 1968) and Aspergillus (Hess \& Stocks, 1969) and basidiospores of various gasteromycetes (Bronchart \& Demoulin, 197I) are covered with a surface rodlet pattern. Wetting of such spores might be prevented by the trapping of air in surface invaginations. Thus the physical conformation of the surface may be sufficient to account for hydrophobic properties (Fisher \& Richmond, 1970). Similar factors have been shown to influence the wetting of the leaves of higher plants (Holloway, 1970).

\section{REFERENCES}

APPlegarth, D. A. (1967). The cell wall of Penicillium notatum. Archives of Biochemistry and Biophysics r20, $47 \mathrm{I}-478$.

Bertaud, W. S., Morice, I. M., Russell, D. W. \& Taylor, A. (1963). The spore surface in Pithomyces chartarum. Journal of General Microbiology 32, 385-395.

Bronchart, R. \& Demoulin, V. (I97I). Ultrastructure de la paroi des basidiospores de Lycoperdon et de Scleroderma (Gastéromycètes) comparée à celle de quelques autres spores de champignons. Protoplasma 72, 179-189.

Douglas, H. W., Ruddick, S. M. \& Williams, S. T. (1970). A study of the electrokinetic properties of some Actinomycete spores. Journal of General Microbiology 63, 289-295.

DYKE, K. G. H. (1964). The chemical composition of the cell wall of the yeast Nadsonia elongata. Biochimica et biophysica acta 82, 374-384.

EmEIs, C. C. (1958). Die Gewinnung von Askosporenmassen von Saccharomyces-Arten auf Grund besonderer Oberflächeneigenschaften. Naturwissenschaften 45, 441.

FisheR, D. J. \& RICHMOND, D. V. (I969). The electrokinetic properties of some fungal spores. Journal of General Microbiology 57, 51-60.

Fisher, D. J. \& Richmond, D. V. (1970). The electrophoretic properties and some surface components of Penicillium conidia. Journal of General Microbiology 64, 205-214.

Haidle, C. W. \& StorCK, R. (I966). Control of dimorphism in Mucor rouxii. Journal of Bacteriology 92 , I236-I 244 .

Herbin, G. A. \& Robins, P. A. (1969). Patterns of variation and development in leaf wax alkanes. Phytochemistry 8, 1985-1998.

Hess, W. M., Sassen, M. M. A. \& Remsen, G. C. (1968). Surface characteristics of Penicillium conidia. Mycologia 60, 290-303.

Hess, W. M. \& Stocks, D. L. (1969). Surface characteristics of Aspergillus conidia. Mycologia 6r, 560-57I.

Hull, M. J., James, A. M. \& MAXTED, W. R. (1963). Some physical investigations of the behaviour of bacterial surfaces. X. The occurrence of lipid in the streptococcal cell wall. Biochimica et biophysica acta 75, 414-424.

HisloP, E. C. (1967). Observations on the vapour phase activity of some foliage fungicides. Annals of Applied Biology 60, 265-279.

Holloway, P. J. (1970). Surface factors affecting the wetting of leaves. Pesticide Science r, 156-I63. 
JAMEs, A. M. (1965). Surface-active agents in microbiology. In Surface Activity and the Microbial Cell, pp. 3-22. Monograph No. 19. London: Society of the Chemical Industry.

JoNES, J. G. (I969). Studies on lipids of soil micro-organisms with particular reference to hydrocarbons. Journal of General Microbiology 59, 145-152.

KANEDA, T. (1969). Hydrocarbons in spinach: two distinctive carbon ranges of aliphatic hydrocarbons. Phytochemistry 8, 2039-2044.

Kreas, K. G., Heusser, D. \& Wimmer, H. (1969). Spray Reagents. In Thin-layer Chromatography, pp. 854908. Edited by E. Stahl. London: George Allen \& Unwin.

Laseter, J. L., Hess, W. M., Weete, J. D., Stocks, D. L. \& Weber, D. J. (I968a). Chemotaxonomic and ultrastructural studies on three species of Tilletia occurring on wheat. Canadian Journal of Microbiology I4, I I 49-I I 54.

LAseter, J. L., Weete, J. \& Weber, D. J. (1968b). Alkanes, fatty acid methyl esters, and free fatty acids in surface wax of Ustilago maydis. Phytochemistry 7, 1177-1 181.

Malins, D. C. \& Mangold, H. K. (1960). Fractionation of fats, oils and waxes on thin layers of silicic acid. Journal of the American Oil Chemists Society 37, 383-384.

Merdinger, E. \& DeVIne, E. M. Jun. (1965). Lipids of Debaryomyces hansenii. Journal of Bacteriology 89, I488-I493.

Oró, J., Laseter, J. L. \& Weber, D. (I966). Alkanes in fungal spores. Science, New York r54, 399-400.

Oró, J., Tornabene, T. G., NoOner, D. W. \& Gelpi, E. (1967). Aliphatic hydrocarbons and fatty acids of some marine and freshwater micro-organisms. Journal of Bacteriology 93, I8I I-1818.

Richmond, D. V. \& Somers, E. (1962). Studies on the fungitoxicity of captan. I. The structural specificity of captan and six $n$-trichloromethythio analogues. Annals of Applied Biology 50, 33-43.

Richmond, D. V. \& Somers, E. (I963). Studies on the fungitoxicity of captan. III. Relation between the sulphydryl content of fungal spores and their uptake of captan. Annals of Applied Biology 52, 327-336.

Shaw, R. (1966). The unsaturated fatty acids of microorganisms. Advances in Lipid Research 4, $107-174$.

SOMERs, E. \& Fisher, D. J. (1967). Effect of dodine acetate on the electrophoretic mobility of Neurospora crassa conidia. Journal of General Microbiology 48, 147-154.

StránskÝ, K., Streibl, M. \& Herout, V. (1967). Distribution of wax hydrocarbons in plants at different evolutionary levels. Collection of Czechoslovak Chemical Communications (English edn) 32, 3212-3220.

Trione, E. J. \& TE MaY Ching (1971). Fatty acids in teliospores and mycelium of the dwarf bunt fungus Tilletia controversa. Phytochemistry ro, 227-229.

Weete, J. D., LASeter, J., Weber, D. J., Hess, W. M. \& Stocks, D. L. (1969). Hydrocarbons, fatty acids, and ultrastructure of smut spores. Phytopathology 59, 545-548. 